\title{
Terrorist group rivalries and alliances: Testing competing explanations
}

\author{
Version accepted at Studies in Conflict \& Terrorism
}

January 2018

\author{
Brian J. Phillips \\ Center for Research and Teaching in Economics (CIDE) \\ Mexico City, Mexico \\ brian.phillips@cide.edu
}

Terrorist group rivalries and alliances have important consequences, but the sources of these relationships are debated. This paper offers a side-by-side examination of correlates of terrorist rivalries and alliances. Global analyses of hundreds of terrorist groups find violent rivalry is associated with drug trafficking, state sponsorship, ethnic motivation, and operating in a civil conflict country. Alliances are associated with territorial control, intermediate membership size, and religious motivation. The idea that alliances are an indicator of weakness does not find much support. When relationships are disaggregated into theoretically-relevant categories (inter-field and intra-field rivalries, and domestic and international alliances), further distinctions appear.

Acknowledgements: I thank Navin Bapat, Jorge Chabat, Ana Carolina Garriga, Jim Piazza, and Eric van Um for their comments. Previous drafts of this paper were presented at the annual meetings of the International Studies Association and the Peace Science Society (International), and at CIDE. I thank participants at these presentations for their comments. 
Some terrorist groups attack each other in violent rivalries, while other terrorist groups form alliances to train or carry out attacks together. Terrorist group rivalries and alliances affect group lethality, tactical choices, longevity, and other outcomes. ${ }^{1}$ According to data used in this paper, about 15 percent of terrorist groups have had a violent rival at some point, and almost half of the groups have had an ally. Other authors find similar rates of participation. ${ }^{2}$ However, debates continue regarding why some terrorist groups form such relationships, while others do not. What types of terrorist groups attack other terrorists? What kinds of terrorist groups form alliances with other groups?

Interorganizational ties between terrorist groups are puzzling because there are reasons why we should expect groups to remain isolated. Regarding violent rivalry, these types of relationships seem counterproductive. Terrorist organizations focus energy on each other instead of the state. This can destroy involved groups, as happened to several Tamil separatist groups in Sri Lanka in the 1980s. ${ }^{3}$ Abrahms cites "terrorist fratricide" as one of the chief puzzles of terrorism, and it is one of the phenomena that lead him to argue that terrorists are not strategic actors. ${ }^{4}$ Regarding alliances, they seem potentially disadvantageous as well, as other authors have explained. ${ }^{5}$ Clandestine actors usually do not have a reliable third party, such as a government or international organization, to help enforce agreements. Additionally, teaming up with other groups could draw increased counterterrorism attention. Related to this, alliances could escalate the risk of counterterrorism success against groups because if one group is infiltrated, security services could find out information about its partner groups as well. These reasons might explain why some groups, such as Peru's Sendero Luminoso, have mostly refused to work with other terrorist organizations. ${ }^{6}$ 
The literature offers contrasting explanations for militant group relationships, as is discussed in more detail below. Some work only looks at relationships among rebel groups in civil wars. It is unclear if the findings from these studies should be applicable to groups that use terrorism, whether in a civil war context or outside of it. Regarding relationships among terrorist groups specifically, it seems that much of this work is dyadic in nature, with interesting results such as the finding that groups with the same ideology or a common target are likely to align. ${ }^{7}$ The dyadic focus is also used for rebel groups, analyzing the role of relative power between the groups. ${ }^{8}$ However, we know little about monadic attributes - characteristics any terrorist group might have on its own - that could explain either violent rivalry or alliances. This paper seeks to complement the extant research by considering arguments that exist in the literature and offering the first side-by-side quantitative global tests of assertions about rivalrous and alliance relationships.

The next section considers the research on relationships among terrorist groups, and presents arguments for why some groups have such relationships. It emphasizes resource-based arguments. The empirical section discusses the data used, and the analyses are conducted on a global data set of terrorist groups, 1987-2005. Results suggest violent rivalries are associated with involvement in the drug business, state sponsorship, ethnic motivation, operating in a democratic country, and operating in a country with a civil war. In contrast with some research, territorial control is not associated with violent rivalry (but see below). Factors associated with terrorist group alliances include controlling territory, intermediate group membership levels, and religious motivation. Despite arguments that alliances are a sign of weakness, evidence is mixed at best regarding this notion. When relationships are disaggregated by theoretically-relevant categories, inter-field and intra-field rivalries as well as domestic and international alliances, 
interesting contrasts appear. For example, inter-field rivalries are negatively associated with territorial control, while intra-field rivalries are positively associated with territorial control. Additionally, international terrorist group alliances are associated with state sponsorship, while domestic terrorist group alliances are not. The conclusion discusses shortcomings of the study and mentions avenues for future research that could draws on the findings.

\section{Terrorist group ties and possible explanations}

Terrorism can be defined as the threat or use of violence by subnational actors to obtain a political or social goal through intimidation of a wider audience beyond their immediate victims. ${ }^{9}$ This manuscript uses a broad understanding of "terrorist groups," but one that is consistent with many studies in the literature: Terrorist groups are subnational political organizations that use terrorism. ${ }^{10}$ In recent years, as global data has become available, scholars have increasingly sought to understand the behavior of organizations that use terrorism. ${ }^{11}$ A substantial number of these studies have examined consequences of terrorist group interactions. There has been less research, however, into the formation of these relationships, or even description of their global patterns. This section discusses some basics of terrorist group relationships and then explains why some group attributes might be related to relationship involvement.

Two types of relationships are frequently discussed in terrorism research: rivalry and alliances. Terrorist groups sometimes attack each other, and when this is a regular occurrence between two groups, it is a violent rivalry. This is related to what some other authors refer to as "competition."12 However, this paper uses a more specific term to imply direct violent interaction, not only groups disagreeing with each other, or coexisting in the same space and indirectly vying for resources. Violent rivalry is consistent with what civil war scholars call 
"fratricide," although they also use this term for within-group violence. ${ }^{13}$ Hafez puts intergroup fratricide at the extreme end of his spectrum of competitive factionalism possible among rebel groups, because a great deal of intergroup competition remains non-violent. ${ }^{14}$ For the purposes of this manuscript, only rivalry between terrorist organizations, as opposed to terrorists and other actor-types (e.g., criminal organizations or informal networks), is considered.

Within violent rivalry, there are intra-field and inter-field rivalries. ${ }^{15}$ Some competitors have the same overall political motivation or ideology, such as communism, representing a particular ethnic group, or Salafism. As an example, Tamil separatist militant groups battled each other in Sri Lanka, and these were intra-field violent rivalries. Other rivals have substantially different views, such as left-wing vs. right-wing, representing one ethnic group vs. representing another, or Sunni vs. Shia. These are inter-field rivalries.

Another common type of terrorist group relationship is cooperation. There are many types of terrorist cooperation, as Moghadam details. ${ }^{16}$ This manuscript focuses on a commonlydiscussed type of cooperation, alliances. I define terrorist group alliances as logistical or operational cooperation between two or more terrorist organizations. Examples include when one group trains another, or when two groups jointly conduct an attack. This is generally consistent with definitions or operationalizations used by other authors. ${ }^{17}$ This material notion of alliances (as opposed to sharing ideas, or only verbal support) is consistent with the International Relations literature on alliances between countries, with the exception that international alliances are often written down, while alliances among terrorist organizations are usually informal in that the terms of the relationship are not inscribed. ${ }^{18}$ As with rivalries, alliances here only refer to relationships involving terrorist groups. Coordination between terrorist groups and other actor types (e.g., nonviolent political parties, informal networks) is beyond the scope of the current study. ${ }^{19}$ Alliances 
can involve groups of the same country, domestic alliances, or groups from different countries, international alliances. $^{20}$

Rivalrous and alliance relationships have occurred in diverse environments around the world. Regarding rivalries, sometimes violent competition starts when a "reactionary" group forms to attack an extant group with opposing political goals. The Autodefensas in Colombia, which formed to attack the FARC and other leftist groups, are an example. ${ }^{21}$ Loyalist groups in Northern Ireland are another. ${ }^{22}$ What seems to be more common, however, is when multiple terrorist groups claim to represent the same ethnic group, and attack each other. This has been evident between terrorist organizations purporting to fight for Catholics in Northern Ireland, Palestinians, Tamils, Kurds, and other ethnopolitical groups. ${ }^{23}$ This “dual contest," groups fighting the government as well as each other, has been widely observed in civil war contexts. ${ }^{24}$

Terrorist group rivalries have important consequences. They can encourage terrorist groups to innovate, to try to find ways to stand out. Bloom argues that this "outbidding" is why groups in competitive situations sometimes adopt the tactic of suicide terrorism. ${ }^{25}$ Some studies suggest competition between terrorist groups results in more terrorism, and more shocking types of attacks. ${ }^{26}$ Other consequences of rivalry include the possibility that the groups get into a spiral of escalating tit-for-tat violence, shifting the nature of conflict from an anti-government struggle to sectarian war. In civil wars, greater factional competition can lead to more civilian deaths. ${ }^{27}$ Finally, rivals can spoil negotiations between the state and a terrorist group or groups. ${ }^{28}$

Regarding alliances, many terrorist groups have trained together, shared logistic networks, or carried out joint attacks. A prominent example is al-Qaeda, which has been a participant in many interorganizational connections. Many other terrorist groups have teamed up with other organizations. Hamas has basically had terrorist group allies ever since its founding in 
the 1980s, and the Colombian group April 19 Movement (M-19) cooperated with other Latin American groups. Alliances do not only happen among groups with similar political goals. For example, Palestinian nationalist terrorist organizations collaborated with European terrorist groups of diverse motivations - nationalist, left-wing, and right-wing. ${ }^{29}$ However, other studies find that generally groups with the same motivations are more likely to form alliances. ${ }^{30}$

When terrorist groups align, they can share resources, spread information, and perhaps increase their capabilities. ${ }^{31}$ Alliances help terrorist groups access new technology and tactics. ${ }^{32}$ Several studies find that groups with allies tend to be much more lethal than those without, and they also tend to survive longer than other groups. ${ }^{33}$ Perhaps for these reasons, terrorist group alliances occur in diverse settings.

Overall, both alliances and violent rivalry occur regularly, involve a broad variety of groups, and substantially affect the involved groups and other actors. What factors are associated with group involvement in of violent rivalries or alliances?

\section{Explanations of violent rivalry}

Some case studies offer explanations of why rivalry or alliances occurred in a specific setting, or with a particular type of group, such as jihadists. ${ }^{34}$ Research on militant group rivalry seems to focus on consequences more than causes, for example looking at how competition leads to tactical innovation, certain conflict outcomes, or ethnic defection. ${ }^{35}$ Other work looks at a related concept, group fragmentation. ${ }^{36}$ Some work is inherently dyadic, such as Hafez's argument about ideological distance within a dyad, among other factors, explaining rivalry dynamics. $^{37}$ 
In contrast to trying to explain rivalry of certain types of groups, or dyadically, this section considers monadic factors that could be associated with rivalry among any terrorist organizations. The framework underlying the discussion of rivalry explanations is resource competition. Terrorist groups depend on resources such as recruits, money, and arms. ${ }^{38}$ The mobilization of these resources is essential for organizational survival and success, ${ }^{39}$ so the following factors are examined: holding territory, involvement in the illegal drug business, and state sponsorship. Competition related to group political motivations, particularly regarding ethnopolitical motivations, is also discussed. Ethnopolitical groups have ties to a certain set of people, and often land, so this implies particular patterns regarding resources, as is discussed below.

When organizations that use terrorism control territory, this provides possible points of contention with other terrorist groups. ${ }^{40}$ Territory can provide income to groups through various forms, such as extortion or exploiting natural resources. Groups then fight over these sources of funds. For example, the Revolutionary Armed Forces of Colombia and the National Liberation Army have attacked each other repeatedly. One point of contention, at least in the early 2000 s, was that the FARC was upset the ELN was not sharing extortion proceeds. ${ }^{41}$ Similarly, Woldemariam argues that changes in territorial control are fundamental for explaining factional infighting within rebel movements. ${ }^{42}$ Controlling territory also means the groups depend on the public for support, and this, too can be a basis for disagreements, including violent competition. ${ }^{43}$ The group controlling the territory might defend the people living there from other groups, ${ }^{44}$ which can turn into interorganizational violence. Through a number of causal mechanisms, then, terrorist groups occupying territory should be likely to engage in violent rivalry. 
Many terrorist organizations are involved in the drug trade, whether production, transportation, or sales of illegal drugs. This has been an important source of funds for a diverse set of groups such as the Democratic Karen Buddhist Army in Myanmar, the Taliban, and the Ulster Volunteer force. Just as holding territory can lead to intergroup competition and violence, the drug trade is also the source of violence between terrorist organizations. The stakes are high in such a lucrative market, and just as drug cartels fight over trade routes and market share, so do terrorist organizations. Fjelde and Nilsson examine groups involved in civil conflict, and find that rivalries are more likely among groups involved in trafficking or production of illegal drugs. ${ }^{45}$ Examples abound of rebel groups fighting over the drug industry, such as in Colombia or Myanmar. Beyond groups in civil wars, it seems likely that involvement in the drug business affects the wider category of groups that use terrorism, given the valuable market associated with these products. Terrorist groups involved with illegal drugs should be especially likely to engage in violent rivalries with other groups.

State sponsorship is a substantial source of resources for many terrorist organizations. ${ }^{46}$ During the Cold War, the United States supported groups such as the Contras in Nicaragua, and the Soviet Union and its allies supported organizations like the Red Brigades in Italy and Germany's Red Army Faction. Beyond the Cold War, Libya supported terrorist organizations for decades. More recently, Syria, Pakistan, Iran, and other states continue to fund groups that use terrorism. ${ }^{47}$ State sponsorship can lead to intergroup rivalry for several reasons. First, the relative wealth of this group can lead to problems with other terrorist organizations, as occurs with other resources such as those mentioned above. Second, the state might want to use the group it is sponsoring to attack a rival state, ${ }^{48}$ or a group that is a proxy for the rival state. Hezbollah has attacked enemies of Iran, its sponsor, for example. Note that it is not necessarily the case that 
sponsorship "causes" rivalry. Rivalry might follow from sponsorship, but a state also might choose to fund a group because that group had already been attacking the state's enemy. Regardless of which occurs first, it seems likely that state sponsorship and rivalry often go together.

A final possible source of rivalry has to do with the political goals of the group. Research shows that differences in motivations can lead to substantial differences in outcomes related to terrorist groups. ${ }^{49}$ Some terrorist groups are primarily motivated by a claim related to an ethnic group, a group of people with a distinctive and enduring identity, based on cultural traits and other attributes. ${ }^{50}$ Sometimes violence among ethnically motivated terrorist organizations is simple sectarian violence, inter-field rivalry among distinct groups - conflict between Loyalists and Republicans in Northern Ireland, for example. (Experts generally consider violence of the Troubles more ethnic than religious. ${ }^{51}$ )

Intra-field conflict also occurs with ethnically motivated militant groups seeking to represent the same community, such as Palestinians or Tamils. ${ }^{52}$ This type of rivalry is often competition for resources such as donations and recruits. ${ }^{53}$ Byman argues that almost all ethnically motivated terrorist groups raise funds from their own community. ${ }^{54}$ This occurs through both donations and extortion, although the line between the two is not always clear. In general, diaspora support for militant groups can be quite lucrative, contributing to their success against the state. ${ }^{55}$ While battles for resources (including donations and recruits) are common among terrorist organizations, intra-field rivalry also occurs due to differences between moderates and relative extremists wanting to represent the ethnic group. ${ }^{56} \mathrm{~A}$ substantial literature shows that disputes involving groups from the same ethnic groups are widespread. ${ }^{57}$ Any type of 
terrorist group could be involved in a violent rivalry, but they seem especially likely among ethnically motivated groups.

\section{Explanations of alliances}

A number of studies theorize sources of terrorist group alliances. Bapat and Bond look at the conditions under which militant groups form particular types of alliances, such as symmetric or asymmetric. ${ }^{58}$ Bacon offers an in-depth analysis of the subject, and argues that a great deal of alliances are explained by "alliance hubs," groups such as al Qaeda, the Popular Front for the Liberation of Palestine, and ISIS, which align with many other groups. ${ }^{59}$ A shared enemy and shared ideology help with partner selection, Bacon argues, but hubs are the crucial element. To complement this argument, however, how else can we explain terrorist group alliances more generally, including the instances that do not involve hubs? Consistent with Bacon's argument, Asal and co-authors find that terrorist groups that share ideologies and are targeting the same

country are more likely to align. ${ }^{60}$ While network and dyadic phenomena are certainly important, monadic factors also contribute to explaining terrorist group alliances.

This section focuses on the following factors likely to affect terrorist group alliances: Holding territory, state sponsorship, group membership size, and religious motivation. The first three factors are important because they are indicative of organizational resources. Groups with such resources are seen as valuable partners by other terrorist groups. They have the capacity to provide resources to other groups, and the capacity to reach out to groups on the other side of the country, region, or world. Religious motivation is also related to organizational resources. Religious groups, often focused on spectacular attacks (see below), are especially likely to draw on alliances to aggregate resources so they can carry out these attacks. 
Holding territory is a crucial element of militant group power, as discussed earlier.

Groups that hold territory tend to kill more people than other groups, for example. ${ }^{61}$ Territory indicates capacity, but also needs. Groups holding territory might be able to supply resources to other terrorist organizations, and they might also need to turn to others for help with security, weapons, training, or other necessities. In short, groups so powerful are unlikely to be able to be isolated. One more specific way in which possessing territory can be associated with intergroup alliances is through training camps. An example is the Moro Islamic Liberation Front, which harbored and trained members of other groups, such as al Qaeda and Jemaah Islamiyah, in their camps. ${ }^{62}$ The training facilities in al Qaeda territory in Afghanistan in the 1990s were also crucial for forging and maintaining relationships with other groups. Holding territory can be a key asset for a terrorist group hub, as it can offer a safe haven, training grounds, or other resources to its alliance partners. ${ }^{63}$

State sponsorship could also be important for explaining intergroup alliances. Funds from governments are resources that terrorist groups can use to support other organizations, through joint training, joint attacks, or simply providing weapons or other goods to their partners. Beyond this type of resource motivation for terrorist group alliances, sponsorship could be related to group alliances because of the desires of the funding country. As with sponsorship and rivalry, it is not always the case that sponsorship "causes" terrorist group alliances. However, relationships with sponsors and with other terrorist groups can influence and bolster each other. Iran has supported both Hezbollah and Palestinian Islamic Jihad, which in turn cooperate with each other. ${ }^{64}$ The Pakistani Inter-Services Intelligence has reportedly supported groups such as Lashkar e Taiba and Hizb ul Mujahideen, which have worked together. ${ }^{65}$ During the Cold War, patterns of state sponsorship overlapped with networks of terrorist organizations, whether in 
Central America, Western Europe, or beyond. This suggests state sponsorship might be especially associated with international alliances as opposed to domestic alliances. The notion that state sponsorship could be associated with group alliances is consistent with Bond's argument that group financial independence is negatively related to alliance formation. ${ }^{66}$

An additional indicator of potential alliances is group size. Some terrorist groups have a handful of members, while others have hundreds or more. The literature suggests contrasting possibilities regarding the relationship between group size and alliance membership. One view is that larger groups are simply more visible, and thus likely to attract potential alliance partners. Given that group size is an indicator of group strength, ${ }^{67}$ it seems probable that stronger groups will be able to reach out, forge, and maintain alliances. Alliances often involve resource sharing, whether through joint training, sharing weapons, or even giving money to another group. Larger groups are better equipped to contribute to such a relationship. Alliance hubs, for example, have all been relatively large groups.

The notion that larger group size could be associated with alliances is debatable because some scholars build on inter-state alliance theory to argue that terrorist group alliances are affected by perceptions of threat - groups form alliances to balance out a more powerful actor. ${ }^{68}$ This is analogous to studies of military alliances between states, which often suggest that the primary function of these alliances is to pool resources against some other actor. ${ }^{69}$ If this capability aggregation motivation was the case generally, we might think that weaker (smaller) groups are more likely to form alliances than more powerful (bigger) groups. Indeed, some analysts and news accounts have suggested that terrorist group alliance involvement is a sign of weakness. ${ }^{70}$ This is consistent with Jackson and colleagues' research on terrorist group learning, which suggests that smaller groups are unlikely to have enough knowledge on their own, and 
need to communicate with external sources - such as other terrorist groups - to compensate for their own resource limitations. ${ }^{71}$

In a third possibility about the relationship between terrorist group size and alliance participation, Bond argues that mid-sized groups are the most likely to form alliances. ${ }^{72}$ She suggests that large (powerful) groups are desirable alliance partners, but they do not have great incentives to join alliances since they already have substantial capabilities. Small groups, on the other hand, will want allies, but others will not see them as worthwhile partners given their low levels of capabilities. Intermediate-sized terrorist groups, however, have the right mix of incentives to align and attractiveness to other partners. Empirical tests can help sort out whether it is larger, smaller, or mid-sized terrorist groups which are especially likely to participate in alliances.

A final factor possibly associated with terrorist group alliances is religious motivation. Religious terrorism, perhaps more than any other type of terrorism, is widely argued to be unique. ${ }^{73}$ Rapoport noted similarities among terrorists motivated by their Hindu, Muslim, or Jewish faith. ${ }^{74}$ Stern suggests religious terrorists are often driven by a desire to "purify the world," which distinguishes them from other terrorists. ${ }^{75}$ Hoffman argues that religious terrorists, as opposed to secular terrorists, have "radically different value systems, mechanisms of legitimization and justification, concepts of morality, and Manichaean world views." ${ }^{, 76}$ Empirical work, including recent work, finds important differences between groups motivated by religion and those with other motivations. ${ }^{77}$ The relatively unique motivations of religious terrorists have implications for their demands for resources, and as a result interactions with other terrorists.

Religious terrorist groups do not seem to have the same level of concern that other terrorist groups do regarding minimizing fatalities, to maintain a degree of political legitimacy. ${ }^{78}$ 
Religious groups are more content with violence as an end than other groups are, and tend to kill far more people than other groups. ${ }^{79}$ Jihadist groups are a prominent example of this, with their dominance of suicide bombing, but in general religious groups are more violent than nonreligious groups. ${ }^{80}$ Allies are an important factor behind terrorist group lethality - even when taking into consideration religious motivations. ${ }^{81}$ Alliances help groups share that enable them to attack in more sophisticated ways, and ultimately kill more people. ${ }^{82}$ Because of the combination of reduced concern about negative consequences of excessive violence and the greater incentives to align to bring about such violence, religious terrorist groups should often be cooperative with other terrorists.

\section{Empirics}

To empirically evaluate the arguments regarding terrorist group relationships while taking other possible explanations into consideration, analyses are conducted on a data set of terrorist groups active at any point between 1987 and 2005. The data are a combination of the terrorist group alliance data and violent rivalry data that I previously published separately. ${ }^{83}$ These data sets were built using a modified version of Asal and Rethemeyer's group data that covered 19982005 as a starting point, ${ }^{84}$ and I gathered data on groups existing as early as 1987, and updated some variables as described below. The Asal and Rethemeyer data was cross-sectional, but when I gathered information on groups from earlier years, I also coded some temporal changes in variables such as the terrorist group relationships. However, the present study uses a crosssection, as did Asal and Rethemeyer, because most organizational independent variables have little or no variation over time. ${ }^{85}$ 
The groups in the data from 1998 or later are the groups from the Asal and Rethemeyer data. ${ }^{86}$ Groups from earlier years are those identified in other terrorist group databases, primarily the Global Terrorism Database (GTD) Terrorist Organization Profiles (TOPs) and the GTD terrorist incident data set. ${ }^{87}$ For years before 1998 , I coded variables using terrorist group databases such as GTD TOPS, as well as newspaper archive searches, books, and other sources. The Lexis-Nexis database was searched for all news articles about each group. These open sources contain a great deal of information about terrorist groups, as terrorist almost by definition publicize their acts - including, often, with whom they act.

The study uses several dependent variables. The primary dependent variables are dichotomous measures of terrorist group violent rivalries and alliances. A terrorist group is coded for Violent rival when another terrorist group physically attacks it or its supporters, or vice versa ${ }^{88} 78$, or about 14 percent, of the groups are coded as having a violent rival. A terrorist group is coded for Alliance when it has shared efforts logistically or operationally with another terrorist organization. This refers to sharing resources, including joint training and joint attacks. This is consistent with the definition of terrorist group alliances discussed by other authors. ${ }^{89}$ This definition excludes mere verbal support because material cooperation is more likely to be consequential. 236, or about 42 percent of groups are coded as being in an alliance.

Dichotomous measures, as opposed to count measures, are used because the argument is about what is associated with having a relationship or not - and not about what explains having an additional or many relationships. Additionally, many have neither adversaries nor allies, so the difference between 0 and 1 is of particular interest, as opposed to, for example, the difference between a second and a third ally. Goodness-of-fit measure suggest that models with binary 
dependent variables offer a better fit than count models. These variables were coded using sources as described above.

For more nuanced understanding of intergroup relationships, additional models also look at disaggregated versions of rivalry and alliances. Rivalry is broken down into inter-field and intra-field rivalries, as discussed previously. These dichotomous variables come from my data on rivalries, and are based on whether the groups are from the same overall ideological "field," or have competing motivations, such as left vs. right, Sunni vs. Shia, or pro-government vs. insurgent. ${ }^{90}$ Intra-field rivalries are more common. Of the 558 groups used in the main models, 27 are coded as having an inter-field rival, while 55 have an intra-field rival. Alliances are divided by those between groups of the same country, and groups from different countries. A group is coded "1" for Domestic alliance if it is in at least one alliance with a group from its own country, and it is coded "1" for international alliance if it is in an alliance with a group from another country. There are more groups with domestic alliances (198) than those with international alliances (91).

Territory is a variable coded 1 if there is evidence of the group controlling territory. To be coded for this, a group should exercise physical control of a substantial part of a country, such as an entire city or swath of rural land large enough for open camps, and the ability to prevent government forces from entering this territory, for an extended period of time. About 16 percent of groups are coded as controlling territory. Drugs is a binary variable coded 1 if evidence is found of organizational involvement in the illegal drug trade, whether production, transportation, or sales. About 7 percent of groups, 45, are coded as having such involvement. State sponsorship is a dichotomous variable coded 1 for groups receiving material support from a government. About 16 percent of groups are coded as being state sponsored. The sources for these variables 
are the same sources as other variables, such as systematic newspaper archive searches, as described in Asal and Rethemeyer's work and my previous articles. ${ }^{91}$

Group size approximates the number of members in a terrorist group. It is an ordinal variable coded 0 if the group has fewer than 100 members, 1 if the group has between 100 and 999 members, 2 if the group has between 1,000 and 9,999 members, and 3 for the few groups with 10,000 or more members. This is not as precise of a measure as we might prefer, but it is the best that is available given the scarcity of information on terrorist group size. The most common value is 0 , fewer than 100 members.

The group motivation measures are Ethnic motivation and Religious motivation, dichotomous measures indicating terrorist groups that have goals related to ethnicity or religion, respectively. Around 35 percent of terrorist groups are coded for Ethnic. About 23 percent are coded for religious. These codings are not exclusive of other motivations, such as leftist or rightist, nor are they mutually exclusive. This broad coding, including groups that have additional motivations, is used because the argument is about groups with a religious or ethnic claim, not necessarily groups that do not have any other additional motivation. The sources for these variables are the same as for the other group variables. Group age is the age in years based on the end year of the group (or 2005 if it was still extant at the end of that year) minus its start year. This is discussed more in the source articles for the data, which deal with terrorist group longevity.

Models also include country-level attributes as control variables. Each terrorist group is coded for the county in which they are primarily located. One country-level factor that indicates opportunities to form relationships is the number of terrorist groups operating in the same 
country. Groups in country is a count measuring the total number of terrorist groups in the country of the group being analyzed.

A proxy of state capacity, Country GDPPC, takes into consideration that certain states have more resources, including resources that could be used for counterterrorism. This measure is particularly relevant for models of alliances, because groups might form alliances to counteract especially capable states. ${ }^{92}$ Country GDPPC measures gross domestic product per capita in thousands of 2005 dollars. The source is Penn World Tables, via the Quality of Government project. $^{93}$ This is a standard, though not ideal, state capability proxy. Fearon and Laitin use it as a measure of "a state's overall financial, administrative, police, and military capabilities.",94

Population, a natural logarithm, is included to capture otherwise unmeasured dynamics within states. For example, terrorist groups tend to last longer in more populous states. ${ }^{95}$ Additionally, it is possible that Groups in country undercounts terrorist organizations due to their clandestine nature, but more populous countries are likely to have more terrorist groups, so Population takes this into consideration. ${ }^{96}$ Population comes from the Penn World Tables.

Models also include Democracy, measured by the Quality of Government's variable that uses an average of Freedom House and Polity data. ${ }^{97}$ When Polity data is missing, the measure imputes based on Freedom House. It is a 0-10 measure, where 10 indicates a highly democratic country. Democracy is included because it has been shown to have important consequences for terrorism. ${ }^{98}$ Models also include Physical integrity rights, from the CIRI project. ${ }^{99}$ It captures to what extent the state is free from physical integrity violations such as disappearances, with a possible value of $0-8$, where 8 indicates freedom from four types of violations. Repression is an important part of the terrorism literature, and it could reduce the abilities of groups to form relationships, or possibly spur them to form alliances. This concept is distinct from Democracy, 
and the two variables are not highly correlated. ${ }^{100}$ Models also include Civil conflict to take into consideration if the country is ever engaged in sustained internal armed conflict. This is a dichotomous variable and it comes from UCDP data. ${ }^{101}$ Finally, models also include regional dummy variables, and the omitted category is the Middle East. Given the binary nature of the dependent variables, logistic regression is used. For a more rigorous test of the hypotheses, models are estimated with robust standard errors. ${ }^{102}$

\section{Findings}

Table 1 reports the results of models. Rivalry is discussed first. Territory is statistically insignificant, suggesting a lack of support for the notion that a terrorist group holding territory is associated with its likelihood of having a rival. This contrasts with Fjelde and Nilsson's study of rebel groups, which found territorial control associated with inter-group violence. Drugs is statistically significant and positively signed, suggesting that group involvement in the illegal drug trade is associated with group participation in violent rivalry. This is consistent with expectations. Similarly, State sponsored is statistically significant and positively signed. Groups with a state sponsor are more likely than groups without a state sponsor to be involved in violent rivalry. None of the three membership size variables are statistically significant, suggesting different group sizes are not associated with rivalry.

[Table 1 about here.]

Ethnic motivation is statistically significant and positively associated with violent rivalry, suggesting this type of group motivation is associated with intergroup violence. Religious 
motivation is not associated with violent rivalry in either model, presenting an interesting contrast across group motivations - and with the alliance results. Both Age and Age squared are statistically significant. Age is positively signed, while Age squared is negatively signed, suggesting a non-linear relationship between age and the likelihood of a group being in a rivalry. As groups get older, they are more likely to have a rival, but this effect decreases at higher ages. Some state-level variables return interesting associations with violent rivalry. Groups in country is not statistically significant, suggesting the extent to which the environment or "market" is crowded is not associated with the likelihood of rivalry. Country GDPPC is associated with violent rivalry. This suggests terrorist groups operating in wealthier countries are more likely to have a violent rival. This is perhaps not an intuitive finding, but it might be driven by the many rivalries among groups in Northern Ireland and Israel (Palestinian Territories). Country population is statistically insignificant. Democracy is statistically significant, suggesting rivalrous relationships are more common in more democratic countries. It could be that groups needs some freedom to be able to attack their peers, and this is more feasible in societies with more civil liberties. Alternately, democracies are said to be likely to give concessions to terrorists, and this could cause groups to fight over negotiation terms. The results for Intra-field rivalry below shed more light on this possibility.

Physical integrity rights is statistically significant and negatively signed, suggesting as countries increasingly protect physical integrity rights of their citizens, rivalries are less likely. This seems to contradict the Democracy finding, but as noted earlier, these variables are not highly correlated and thus represent different aspects of rights. This is worthy of further investigation. Civil conflict is statistically significant and positively associated with violent rivalry in both models, suggesting terrorist groups in countries that have had civil conflicts are 
more likely to have rivals. Of the region variables, only Asia has a statistically significant coefficient, suggesting groups in this region are more likely than groups in the Middle East, the omitted category, to have rivals. Some countries in Asia with group rivalries include India, Indonesia, Pakistan, and Sri Lanka (in the 1980s).

Regarding the alliance model, Model 2, Territory is associated with having an alliance. This is consistent with expectations. Drugs and State sponsorship are statistically insignificant. This is an interesting contrast with the violent rivalry results. Of the membership size measures, the variable representing 100-999 members is statistically significant and positively. This suggests groups with between 100 and 999 members are more likely than groups with less than 100 members (the omitted category) to have a rival. This is interesting because size is often a measure of group strength, so this finding goes against notions that alliances are a sign of weakness. The result is consistent with Bond's notion of intermediate-sized groups being especially likely to participate in alliances. The 100-999 group member category could be considered "intermediate" since very few $(<5 \%)$ of the groups are in the largest category. Effectively there are three categories, the middle of which is 100-999 members.

Ethnic motivation is statistically insignificant, but Religious motivation is statistically significant and positively signed, suggesting religious groups are more likely than other types of groups to be in alliances. This is consistent with expectations. The ethnic and religious findings regarding alliances jointly present an interesting divergence from the violent rivalry findings. Age and Age squared are both statistically significant, positively and negatively signed respectively, suggesting a nonlinear relationship similar to what was seen with violent rivalry.

Terrorist group cooperation is not associated with many state-level variables. Groups in country is statistically significant and positively signed (although only marginally significant, 
$p<.10)$. This suggests that if a group is in a country with a higher number of terrorist groups, it is more likely to have an ally. This is intuitive. Country GDPPC, Population (log), and Democracy are all statistically insignificant. Group-level variables seem to better explain group alliances. The lack of significance for Country GDPPC is interesting because state per capita wealth is often a measure of state capacity, and the insignificance suggests a lack of support for the notion that groups facing stronger states are more likely to join alliances.

Physical integrity rights is statistically significant and negatively signed. The more that a state respects physical integrity rights, for example refraining from "disappearing" citizens, the less likely a terrorist group in that country is to align with another group. Perhaps group alliances are more helpful when groups face repression, so groups can team up against the state. This is the only hint of support for the capability aggregation model of alliance participation. Civil conflict is statistically insignificant, which is another difference with the rivalry results. None of the regional variables are statistically significant in Model 2, suggesting there is no difference between groups in these regions and those of the Middle East (the omitted category) in terms of the likelihood of alliance participation.

[Figure 1 about here.]

Marginal effects (see Figure 1) are used to calculate substantive significance of variables in Table 1, the primary models. Regarding violent rivalry, involvement in the illegal drug business is associated with a 7 percent increase in the likelihood of having a rival. State sponsorship is associated with a bigger impact, a 9 percent increase in the likelihood of having a terrorist group rival. Having an ethnic motivation is associated with a 7 percent increase in rival 
likelihood. Regarding terrorist group age, each additional year of a group's existence is associated with a 1 percent increase in the likelihood of a group having a rival. State-level independent variables, when significant, are usually associated with only minor changes in the likelihood of a rivalry. The substantial exception is Civil conflict, which has the largest estimated impact of the model. A group in a civil conflict country is expected to have a 21 percent increase in the chance of having a terrorist group rival.

Regarding the alliance dependent variable, shown in the right-hand panel of Figure 1, holding territory is associated with a 12 percent increase in the likelihood of a group having an ally. Having between 100-999 members is associated with a 21 percent increase in the likelihood of having a rival, relative to groups with fewer than 100 members. Religious motivation is also associated with about a 21 percent increase in the likelihood of rivalry, making group size and religious motivation the most substantively important variables in the alliance model. An increase in respect for physical integrity rights in the country a group operates in is associated with a 4 percent decrease in a group's likelihood of having an ally.

\section{Inter-field and intra-field violent rivalry}

Table 2 shows models with the violent rivalry dependent variable disaggregated by whether the group has an inter-field or intra-field rival. Territory is statistically significant and negatively related to inter-field rivalry, but is statistically significant and positively related to intra-field rivalry. One reason this is noteworthy is because in Model 1, with the aggregated Violent rivalry dependent variable, the coefficient on Territory was statistically insignificant. Results in Model 3 suggest this insignificance might have occurred because the divergent effects cancel each other out when both rivalry types are combined. The negative sign for inter-field 
rivalry might occur because this type of rivalry often involves right-wing or pro-government groups, which seem to be less likely to hold territory. The positive sign for intra-field rivalry is expected given the discussion earlier, particularly Woldemariam's claim that territorial issues can lead to fragmentation and fratricide among rebels. ${ }^{103}$

Another difference between Models 3 and 4 is that intermediate-sized groups (100-9,999 members) are negatively associated with inter-field rivalry, suggesting these groups are less likely than smaller groups to have a rival. In other words, groups with inter-field rivals tend to be small. Meanwhile, intra-field rivalry is associated with groups in the category of 1,000-9,999 members. Groups with intra-field rivals tend to be larger. The small size of groups more likely to have inter-field rivals is consistent with the notion of pro-government groups. The relationship between large size and intra-field rivalry is consistent with the idea of resource-rich groups drawing enemies. This especially seems likely regarding groups that might compete for the same membership base - groups with similar political goals, intra-field rivals.

A final distinction is that intra-field rivalry is associated with several country factors (Country GDPPC, Democracy, and Physical integrity rights), while inter-field rivalry is not associated with any of them. The explanation for all these differences is not clear, but one reason why intra-field rivalry might be more likely in democratic countries involves the potential for concessions. Democratic governments are often willing to give concessions to militant groups in exchange for peace, ${ }^{104}$ and this can lead to infighting between terrorist groups of the same wider movement - particularly regarding relative extremists that are not willing to negotiate. ${ }^{105}$ This could explain the association between democratic regime type and intra-field rivalries.

\section{Domestic and international alliances}


Models 5 and 6 have domestic and international alliances as the respective dependent variables. There are three main differences. First, State sponsored is associated with international alliances, but not domestic alliances. (In Model 2, with the aggregate alliance dependent variable, State sponsored was statistically insignificant.) Despite theoretical reasons why state sponsorship might be related to alliances generally, it appears there is only a connection between sponsorship and international alliances. This is interesting and worthy of future research. The results suggest that state sponsorship and international alliances could be seen as complements, not substitutes.

A second difference is that Groups in country, the count of other terrorist groups in the same country, is only associated with domestic alliances. This suggests opportunity plays a role in the formation of domestic alliances, but that a crowded market does not necessarily push groups toward international alliances. Third, Sub-Saharan Africa is statistically significant and negatively signed, suggesting that groups from this region are less likely than groups from the Middle East (the omitted category) to have international allies. Overall, the disaggregation of violent rivals and allies adds interesting nuance to our understanding of these types of relationships.

\section{Conclusion}

This paper presented statistical evidence of connections between terrorist group attributes and the presence of rivalrous or alliance relationships. Most of the relationships can be seen in the framework of resource mobilization: resource competition regarding rivalry, and resource aggregation regarding alliances. Some factors associated with interorganizational rivalry are involvement in the drug business, state sponsorship, ethnic motivation, and operating in a country with a civil war or a democratic country. Terrorist group alliances are generally associated with 
controlling territory, moderate group size (100-999 members), and religious motivation. Results show interesting differences when rivalries are disaggregated into the categories of inter-field and intra-field rivalries, and alliances are broken down by whether they are international or domestic.

These findings contribute to the growing line of research seeking to understand a common terrorist group behavior, direct engagement with other terrorist groups. These relationships make terrorist groups more lethal, encourage and enable dangerous innovation, contribute to group longevity, and can harm the peace process between states and relatively moderate terrorist groups. Recent research has made important advances understanding rivalry and alliances, usually though qualitative and/or dyadic analysis. The current manuscript complements this work with its quantitative and monadic focus, confirming some arguments in the literature, but challenging others, particularly related to group strength and alliances.

Limitations of the research should be acknowledged. While the theorized causal mechanisms are discussed, these mechanisms are not tested in the empirical analyses. Extant theory and anecdotal evidence suggest that the mechanisms are plausible. The manuscript shows supportive evidence, but additional research is needed regarding causal mechanisms. In-depth case studies or additional quantitative data could provide additional tests. Additionally, the data only covers up through 2005, so it cannot tell us about, for example, ISIS as it exists today. The sample does include hundreds of terrorist organizations, a broad range of groups of virtually all types, but future research should see if the relationships found here hold up in more recent samples.

The manuscript's findings lay groundwork for continued study of these important topics. First, given the explanations of terrorist group relationships, should we take this into consideration when studying the consequences of relationships? In other words, perhaps results 
of extant studies on the effects of terrorist group alliances or rivalries might change if relationships are endogenized in a two-stage model. Second, the results suggest some differences among ethnic and religious terrorist groups in terms of their propensity to have rivalries or alliances with other groups. What other ways can these motivations explain terrorist group behavior?

Third, what can the findings of this paper tell us about the more specific but overlapping set of militant groups involved in civil war? Regarding violent rivalry, some of the findings of the current manuscript also appear in studies of rebel groups, such as the relationship between illegal drugs and rivalry. Some of my other results do not match up directly with those from rebel group studies. My results suggest territorial control is not associated with violent rivalry generally, but when categories are disaggregated, territory is associated only with intra-field rivalry. This contrasts with Fjelde and Nilsson's finding that territorial control is associated generally with rebel group rivalry. Regarding alliances, direct comparisons with the civil war literature are not clear cut, but some differences could be further explored. The primary study of rebel group alliances is Christia's book, which examines alliances dyadically. Christia finds relative power is more important than ideological motivations for explaining alliances. The present paper finds religious motivations are more consistently related to alliance involvement than group strength measures are. The monadic focus of this work makes the two studies not analogous in a straightforward way, but the apparent contrasts are interesting. Additional research is needed on rebel group alliances to better understand their roots, and to what extent they compare to those of terrorist group alliances.

Finally, regarding the notion in the literature and news media that relatively weak terrorist groups join alliances, this idea found almost no support. Intermediate-sized terrorist groups are 
the most likely to have allies, consistent with some less-common arguments in the literature. If group weakness explained terrorist group alliances, we would expect the smallest groups to be the most likely to have allies. Controlling territory, another indicator of group strength, is also associated with alliances. This suggests stronger groups are more likely to have allies. State capacity, proxied by GDP per capita, was not associated with alliance involvement, despite arguments that groups should form alliances when facing strong states. More work is needed to understand the relationship(s) between terrorist group strength and alliance participation. However, the conventional wisdom about group weakness and alliances might not be valid, or might only apply in certain circumstances.

Overall, this manuscript has shed light on some factors associated with rivalry or alliances, and it turns out group resource measures are consistently associated with one type of relationship or the other. This can be a building block for work on related aspects of terrorist group relationships. Given the consequential nature of rivalries and alliances among terrorist organizations, additional research can contribute to our understanding of the sources and patterns of these important relationships. 
Table 1. Models of terrorist group violent rivalry or alliances, 1987-2005

\begin{tabular}{lcc}
\hline & $\begin{array}{c}\text { Model 1 } \\
\text { Dependent variable: } \\
\text { Violent rivalry }\end{array}$ & $\begin{array}{c}\text { Model } 2 \\
\text { Dependent variable: } \\
\text { Alliance }\end{array}$ \\
\hline Territory & $.347(.478)$ & $.763^{* *}(.378)$ \\
Drugs & $1.120^{* *}(.446)$ & $.171(.471)$ \\
State sponsored & $1.405^{* * *}(.461)$ & $-.103(.356)$ \\
$100-999$ members & $-.363(.563)$ & $1.375^{* * *}(.348)$ \\
$1,000-9,999$ members & $.309(.538)$ & $-.057(.448)$ \\
10,000 or more members & $.600(.711)$ & $.455(.620)$ \\
Ethnic motivation & $.991^{* *}(.478)$ & $.233(.254)$ \\
Religious motivation & $-.375(.438)$ & $1.324^{* * *}(.345)$ \\
Age & $.135^{* * *}(.042)$ & $.113^{* * *}(.019)$ \\
Age squared & $-.001^{*}(.001)$ & $-.001^{* * *}(.000)$ \\
Groups in country & $-.0429(.0297)$ & $.025^{*}(.015)$ \\
Country GDPPC & $.131^{* * *}(.045)$ & $.029(.022)$ \\
Population (log) & $-.0178(.180)$ & $.009(.098)$ \\
Democracy & $.316^{* *}(.144)$ & $.104(.075)$ \\
Physical integrity rights &. $.360^{* * *}(.124)$ & $-.246^{* * *}(.078)$ \\
Civil conflict & $3.132^{* * *}(1.082)$ & $-.0827(.345)$ \\
Asia & $3.138^{*}(1.847)$ & $-.236(1.045)$ \\
Sub-Saharan Africa & $1.745(1.766)$ & $-1.196(1.020)$ \\
Europe & $.713(1.803)$ & $-.163(.850)$ \\
Americas & $1.490(1.756)$ & $.003(.915)$ \\
Constant & $-10.22^{* * *}(2.424)$ & $-2.441^{* *}(1.062)$ \\
\hline Observations & 558 & 558 \\
\hline
\end{tabular}

Models estimated with logistic regression. Robust standard errors are shown in parentheses. $* p<.10, * * p<.05, * * * p<.01$ 
Table 2. Models of terrorist group violent rivalry, disaggregated by rivalry type, 1987-2005

\begin{tabular}{lcc}
\hline & $\begin{array}{c}\text { Model } 3 \\
\text { Dependent variable: } \\
\text { Inter-field rivalry }\end{array}$ & $\begin{array}{c}\text { Model } 4 \\
\text { Dependent variable: } \\
\text { Intra-field rivalry }\end{array}$ \\
\hline Territory & $-1.865^{* *}(.906)$ & $1.694^{* *}(.670)$ \\
Drugs & $.942(.596)$ & $.414(.564)$ \\
State sponsored & $1.837^{* *}(.777)$ & $.978^{* *}(.475)$ \\
$100-999$ members & $-1.626^{* *}(.672)$ & $1.030(.645)$ \\
$1,000-9,999$ members & $-2.022^{* * *}(.766)$ & $1.899^{* * *}(.680)$ \\
10,000 or more members & $.089(.854)$ & $1.332(.811)$ \\
Ethnic motivation & $.865(.616)$ & $1.121(.684)$ \\
Religious motivation & $-1.277(.877)$ & $.053(.472)$ \\
Age & $.236^{* * *}(.066)$ & $.093^{* * *}(.028)$ \\
Age squared & $-.004^{* * *}(.001)$ & $-.001^{* * *}(.000)$ \\
Groups in country & $-.074(.046)$ & $-.020(.037)$ \\
Country GDPPC & $.057(.068)$ & $.175^{* * *}(.049)$ \\
Population (log) & $.177(.217)$ & $.092(.235)$ \\
Democracy & $.012(.147)$ & $.392^{* *}(.172)$ \\
Physical integrity rights & $-.153(.196)$ & $-.363^{* * *}(.138)$ \\
Civil conflict & $3.504^{* *}(1.779)$ & $3.126^{* * *}(1.029)$ \\
Asia & $.933(1.693)$ & $1.730(2.247)$ \\
Sub-Saharan Africa & $.249(1.924)$ & \\
Europe & $.177(2.045)$ & $-.389(2.255)$ \\
Americas & $1.012(2.015)$ & $-.481(2.227)$ \\
Constant & $-10.80^{* * *}(3.377)$ & $-13.72^{* * *}(3.196)$ \\
\hline Observations & 558 & 531 \\
\hline
\end{tabular}

Models estimated with logistic regression. Robust standard errors are shown in parentheses. Groups from Sub-Saharan Africa drop from Model 4 because none are coded for intra-field rivalry. ${ }^{*} p<.10,{ }^{* *} p<.05,{ }^{* * *} p<.01$ 
Table 3. Models of terrorist group alliance, disaggregated by alliance type, 1987-2005

\begin{tabular}{lcc}
\hline & $\begin{array}{c}\text { Model } 5 \\
\text { Dependent variable: } \\
\text { Domestic alliance }\end{array}$ & $\begin{array}{c}\text { Model 6 } \\
\text { Dependent variable: } \\
\text { International alliance }\end{array}$ \\
\hline Territory & $.146(.338)$ & $.644(.403)$ \\
Drugs & $-.035(.402)$ & $.983(.609)$ \\
State sponsored & $.124(.326)$ & $1.030^{* * *}(.352)$ \\
$100-999$ members & $1.003 * * *(.328)$ & $1.286^{* * *}(.403)$ \\
$1,000-9,999$ members & $.269(.381)$ & $.664(.528)$ \\
10,000 or more members & $.830(.532)$ & $-.318(.829)$ \\
Ethnic motivation & $.150(.245)$ & $-.177(.365)$ \\
Religious motivation & $.869 * * *(.296)$ & $1.591 * * *(.344)$ \\
Age & $.075 * * *(.016)$ & $.191 * * *(.048)$ \\
Age squared & $-.000^{* * *(.000)}$ & $-.003 * * *(.001)$ \\
Groups in country & $.037 * *(.015)$ & $-.012(.020)$ \\
Country GDPPC & $.031(.0212)$ & $-.003(.030)$ \\
Population $(l o g)$ & $-.129(.105)$ & $.006(.114)$ \\
Democracy & $.099(.073)$ & $.077(.088)$ \\
Physical integrity rights & $-.186 * *(.072)$ & $-.226 * *(.108)$ \\
Civil conflict & $.389(.341)$ & $-.733(.447)$ \\
Asia & $1.138(1.063)$ & $-1.064(1.126)$ \\
Sub-Saharan Africa & $.220(1.049)$ & $-2.954 * *(1.387)$ \\
Europe & $.757(.892)$ & $-.119(1.036)$ \\
Americas & $1.057(.953)$ & $-.557(1.009)$ \\
Constant & $-1.615(1.055)$ & $-3.198^{* * *}(1.215)$ \\
\hline Observations & 558 & 558 \\
\hline
\end{tabular}

Models estimated with logistic regression. Robust standard errors are shown in parentheses. $* p<.10, * * p<.05, * * * p<.01$ 


\section{Figure 1. Marginal effects of variables in Models 1 and 2}
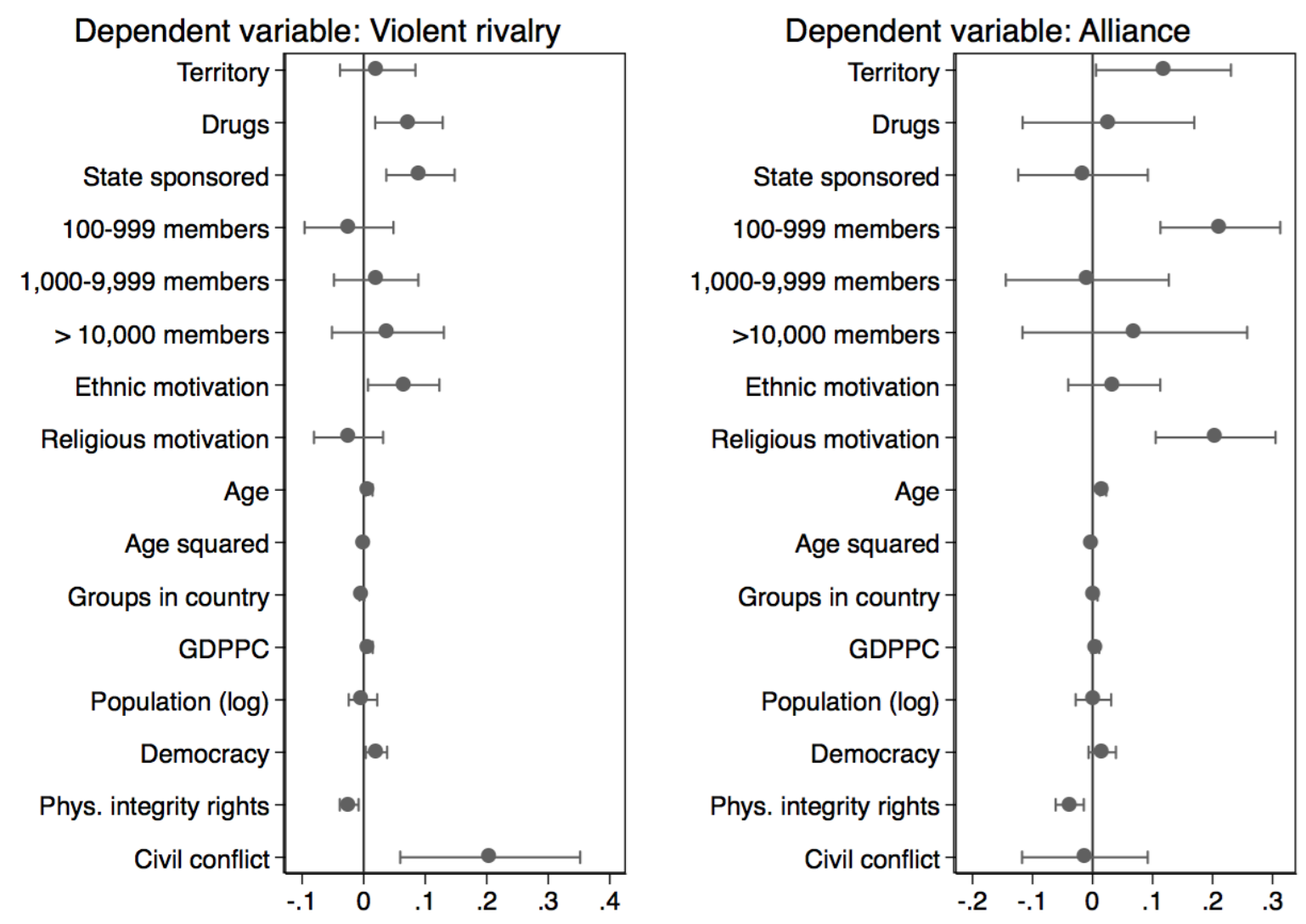

Figure shows average marginal effect of variables, with 95 percent confidence intervals. 


\section{Notes}

${ }^{1}$ E.g., Victor Asal and Karl Rethemeyer, "The Nature of the Beast: Organizational Structures and the Lethality of Terrorist Attacks," Journal of Politics 32 (2008), pp. 437-449; Justin Conrad and Kevin Greene, "Differentiation and the Severity of Terrorist Attacks," Journal of Politics 2 (77) (2015), pp. 546-561.

${ }^{2}$ Fjelde and Nilsson's analysis of rebel groups finds that about 18 percent of the groups had a violent rival. Regarding allies, about 54 percent of terrorist groups in the Asal and Rethemeyer data have an ally. Similarly, Akcinaroglu finds that 52 percent of rebel groups in the UCDP data have an ally. Seden Akcinaroglu, "Rebel interdependencies and civil war outcomes," Journal of Conflict Resolution 56 (5) (2012), pp. 879-903; Asal and Rethemeyer, "The Nature of the Beast;" Hanne Fjelde and Desirée Nilsson, "Rebels against rebels: Explaining violence between rebel groups," Journal of Conflict Resolution 56 (4) (2012), pp. 604-628.

${ }^{3}$ Kenneth Bush, The Intra-group Dimensions of Ethnic Conflict in Sri Lanka: Learning to Read Between the Lines (New York: Palgrave Macmillan, 2003).

${ }^{4}$ Max Abrahms, "What Terrorists Really Want: Terrorist Motives and Counterterrorism Strategy," International Security 4 (32) (2008), pp. 78-105.

${ }^{5}$ Tricia Bacon, "Hurdles to International Terrorist Alliances: Lessons From Al Qaeda's Experience," Terrorism and Political Violence 20 (1) (2017), pp. 79-101; Navin Bapat and Kanisha D. Bond, "Alliances Amongst Militant Groups," British Journal of Political Science 4 (42) (2012), pp. 793-824.

${ }^{6}$ Gordon H. McCormick, "The Shining Path and Peruvian Terrorism," in David C. Rapoport ed., Inside Terrorist Organizations (London: Frank Cass, 2001), pp. 109-128, at pp. 120-121.

${ }^{7}$ Victor Asal, Hyun Hee Park, Karl Rethemeyer and Gary Ackerman, "With Friends Like These...Why Terrorist Organizations Ally," International Public Management Journal 19 (1) (2016), pp. 1-30; Tricia Bacon, Strange Bedfellows or Brothers in Arms: Why Terrorist Groups Ally (Dissertation, Georgetown University, 2013); Tricia Bacon, "Is the Enemy of My Enemy My Friend? How Terrorist Groups Select Partners," Security Studies (2018), online first.

${ }^{8}$ E.g., Fotini Christia, Alliance Formation in Civil Wars (Cambridge: Cambridge University Press, 2012).

${ }^{9}$ Walter Enders and Todd Sandler, The Political Economy of Terrorism (Cambridge: Cambridge University Press, 2012).

${ }^{10}$ The definition comes from Brian J. Phillips, "What is a Terrorist Group? Conceptual Issues and Empirical Implications," Terrorism and Political Violence 27 (2) (2015): 225-242. This is a broad notion of "terrorist groups," as it includes groups that also engage in other tactics, such as guerrilla warfare. However, many other authors use this definition implicitly or explicitly when discussing groups such as the FARC or the PKK as terrorist groups. For more discussion see David B. Carter, "A blessing or a curse? State support for terrorist groups," International Organization 66 (1) (2012), pp. 129-151; Luis de la Calle and Ignacio Sánchez-Cuenca, "What we talk about when we talk about terrorism," Politics \& Society 39 (3) (2011), pp. 451-472; Seth G. Jones and Martin C. Libicki, How Terrorist Groups End: Lessons for Countering al Qa'ida (Washington, D.C.: RAND, 2008).

${ }^{11}$ E.g., Audrey Kurth Cronin, How Terrorism Ends: Understanding the Decline and Demise of Terrorist Campaigns (Princeton: Princeton University Press, 2009); Jenna Jordan, "When Heads 
Roll: Assessing the Effectiveness of Leadership Decapitation," Security Studies 4 (18) (2009), pp. 719-755.

${ }^{12}$ Mia Bloom, Dying To Kill: The Allure of Suicide Terrorism (New York: Columbia University Press, 2005).

${ }^{13}$ Paul Staniland. "Between a Rock and a Hard Place: Insurgent Fratricide, Ethnic Defection, and the Rise of Pro-State Paramilitaries," Journal of Conflict Resolution 56 (1) (2012): 16-40. For example, Staniland references fratricide "across or within insurgent groups."

${ }^{14}$ Mohammed M. Hafez, "Fratricidal Rebels: Ideological Extremity and Warring Factionalism in Civil Wars," Terrorism and Political Violence (2017), online first.

${ }^{15}$ Brian J. Phillips, "Enemies with Benefits? Violent Rivalry and Terrorist Group Longevity," Journal of Peace Research 1 (52) (2015), pp. 62-75. For examples, see Bacon, "Is the Enemy of My Enemy My Friend?" and Hargie, Owen, and Pauline Irving, "Making Sense of

Communication in Societies Divided by Terrorism: Lessons from Northern Ireland," pp.46-71 in Ian Somerville, Owen Hargie, Maureen Taylor, and Margalit Toledano (eds.), International Public Relations: Perspectives from Deeply Divided Societies (London: Routledge, 2017), pp. 55-56.

${ }^{16}$ Assaf Moghadam, Nexus of Global Jihad: Understanding Cooperation Among Terrorist Actors (New York: Columbia University Press, 2017).

${ }^{17}$ Tricia Bacon, Strange Bedfellows or Brothers in Arms; Brian J. Phillips, How Terrorist Organizations Survive: Cooperation and Competition in Terrorist Group Networks (Dissertation, University of Pittsburgh, 2012). Bacon stipulates that alliances also include expectations for future cooperation, but I omit this because it is difficult to know with certainty, especially when gathering data on many groups. Karmon initially defines what he calls "coalitions" as ideological, logistical, or operational cooperation (p. 7). However, he later argues that for the purposes of his book, he does not include ideological cooperation as sufficient for a coalition relationship. Only logistical and operation cooperation is sufficient (p. 50). Ely Karmon, Coalitions Between Terrorist Organizations: Revolutionaries, Nationalists and Islamists (Netherlands: Nijhoff Publishers, 2005).

${ }^{18}$ Walt defines an alliance as a formal or informal relationship of security cooperation between two or more sovereign states. Walt, Stephen M., Origins of Alliance Formation (Cornell: Cornell University Press, 1987).

${ }^{19}$ For an innovative discussion of terrorist group cooperation with other kinds of actors, see Moghadam, Nexus of Global Jihad.

${ }^{20}$ For example, Bacon, "Hurdles to International Terrorist Alliances."

${ }^{21}$ Mauricio Romero, Paramilitares y Autodefensas 1982-2003 (Bogotá: Universidad Nacional de Colombia, 2003).

${ }^{22}$ Steve Bruce, The Red Hand: Protestant Paramilitaries in Northern Ireland (New York: Oxford University Press, 1992).

${ }^{23}$ Kenneth Bush, The Intra-group Dimensions of Ethnic Conflict in Sri Lanka: Learning to Read Between the Lines (New York: Palgrave Macmillan, 2003); Ric Clarke, "Vicious Irish guerrilla feud claims more victims," United Press International, March 9, 1987; Michael M. Gunter, "The KDP-PUK Conflict in Northern Iraq,” Middle East Journal 2 (50) (1996), pp. 224-241.

${ }^{24}$ Kathleen Gallagher Cunningham, Kristin M. Bakke, and Lee J. M. Seymour, "Shirts Today, Skins Tomorrow Dual Contests and the Effects of Fragmentation in Self-Determination Disputes," Journal of Conflict Resolution 1 (56) (2012), pp. 67-93. 
${ }^{25}$ Bloom, Dying to Kill. However, the competition that leads to outbidding is not necessarily violent rivalry, as groups often try to outbid each other without enganging in violence towards each other.

${ }^{26}$ Erica Chenoweth, "Democratic Competition and Terrorist Activity," Journal of Politics 1 (72) (2010), pp. 16-30; Justin Conrad and Kevin Greene, "Differentiation and the Severity of Terrorist Attacks," Journal of Politics 2 (77) (2015), pp. 546-561; Stephen Nemeth, "The Effect of Competition on Terrorist Group Operations," Journal of Conflict Resolution 2 (58) (2014), pp. 336-362.

${ }^{27}$ Cunningham et al., "Shirts Today, Skins Tomorrow Dual Contests and the Effects of Fragmentation in Self-Determination Disputes."

${ }^{28}$ Andrew Kydd and Barbara F. Walter, "Sabotaging the Peace: The Politics of Extremist Violence," International Organization 2 (56) (2002), pp. 263-296; Wendy Pearlman, "Spoiling Inside and Out: Internal Political Contestation and the Middle East Peace Process", International Security 3 (33) (2009), pp. 79-109.

${ }^{29}$ Karmon, Coalitions Between Terrorist Organizations.

${ }^{30}$ Asal et al., "With Friends Like These."

${ }^{31}$ Michael C. Horowitz, "Nonstate Actors and the Diffusion of Innovation: The Case of Suicide Terrorism," International Organization 1 (64) (2010), pp. 33-64.

${ }^{32}$ Asal et al., "With Friends Like These."

${ }^{33}$ Asal and Rethemeyer., "The Nature of the Beast;" Michael C. Horowitz and Phillip B. K. Potter, "Allying to Kill: Terrorist Intergroup Cooperation and the Consequences for Lethality," Journal of Conflict Resolution 2 (58) (2014), pp. 199-225; Brian J. Phillips, "Terrorist Group Cooperation and Longevity," International Studies Quarterly 2 (58) (2014), pp. 336-347. ${ }^{34}$ Bruce, The Red Hand; Fawaz A. Gerges, The Far Enemy: Why Jihad Went Global. (New York: Cambridge University Press, 2005); Assaf Moghadam and Brian Fishman (eds.) Fault Lines in Global Jihad: Organizational, Strategic, and Ideological Fissures (New York: Routledge, 2011); David T. Schiller, "A Battlegroup Divided: The Palestinian Fedayeen," in David C. Rapoport ed., Inside Terrorist Organizations (London: Frank Cass, 2001), pp. 90-108; Eric Van Um, Evaluating the Political Rationality of Terrorist Groups. (Springer, 2016), especially Chapter 3.

${ }^{35}$ Bloom, Dying to Kill; Cunningham et al., "Shirts Today, Skins Tomorrow Dual Contests and the Effects of Fragmentation in Self-Determination Disputes;" Staniland, "Between a Rock and a Hard Place: Insurgent Fratricide, Ethnic Defection, and the Rise of Pro-State Paramilitaries."

${ }^{36}$ Cunningham et al., "Shirts Today, Skins Tomorrow Dual Contests and the Effects of Fragmentation in Self-Determination Disputes."

${ }^{37}$ Hafez, "Fratricidal Rebels."

${ }^{38}$ Shapiro, Jacob N. The Terrorist's Dilemma: Managing violent covert organizations. (Princeton: Princeton University Press, 2013).

${ }^{39}$ McCarthy, John D., and Mayer N. Zald, "Resource Mobilization and Social Movements: A Partial Theory," American Journal of Sociology 82, 6 (1977): 1212-1241.

${ }^{40}$ Some scholars argue that militant groups that control territory are better thought of as guerrilla organizations. However, many prominent scholars have referred to groups such as the FARC and Hezbollah as terrorist organizations, and prominent data sets such as Jones and Libicki include territory-controlling groups among the "terrorist groups," and we use this broader idea of the 
concept as well. See de la Calle and Sánchez-Cuenca, "What we talk about when we talk about terrorism."

${ }^{41}$ Scott Wilson, "U.S. Moves Closer to Colombia's War; Involvement of Special Forces Could Trigger New Wave of Guerrilla Violence," Washington Post, February 7, 2003.

${ }^{42}$ Woldemariam, Michael, "Battlefield Outcomes and Rebel Cohesion: Lessons from the Eritrean Independence War," Terrorism and Political Violence 28 (1) (2016): 135-156.

${ }^{43}$ Bloom, Dying to Kill.

${ }^{44}$ Zachariah Cherian Mampilly, Rebel rulers: Insurgent governance and civilian life during war (Cornell University Press, 2011), p. 4.

${ }^{45}$ Hanne Fjelde and Desirée Nilsson, "Rebels against rebels."

${ }^{46}$ Carter, "A blessing or a curse? State support for terrorist groups."

${ }^{47}$ Daniel Byman, Deadly Connections: States That Sponsor Terrorism (Cambridge University Press, 2005); Daniel Byman, The changing nature of state sponsorship of terrorism (Washington, D.C.: Brookings, 2008).

${ }^{48}$ Navin Bapat, "Understanding state sponsorship of militant groups," British Journal of Political Science 42 (1) (2012), pp. 1-29.

${ }^{49}$ Asal and Rethemeyer, "The Nature of the Beast"; James A. Piazza, "A Supply-Side View of Suicide Terrorism: A Cross-National Study," Journal of Politics 1 (70) (2008), pp. 28-39; Brandon M. Boylan, "What Drives Ethnic Terrorist Campaigns? A View at the Group Level of Analysis," Conflict Management and Peace Science 33, 3 (2016): 250-272; Gregory D. Miller, "Confronting Terrorisms: Group Motivation and Successful State Policies," Terrorism and Political Violence 3 (19) (2007), pp. 331-350.

${ }^{50}$ Daniel Byman, "The Logic of Ethnic Terrorism," Studies in Conflict and Terrorism 2 (21) (1998), pp. 149-169, fn. 1; Ted Robert Gurr, Peoples Versus States: Minorities at Risk in the New Century (Washington, D.C.: United States Institute of Peace, 2000).

${ }^{51}$ For example, see Carolyn Gallaher, After the Peace: Loyalist Paramilitaries in Post-Accord Northern Ireland (Ithaca: Cornell University Press, 2007), pp. 30-31.

${ }^{52}$ Van Um, "Why Militant Groups Fight Each Other." Analysis of the Troubles suggests that a great deal of the inter-group violence occurred between groups on the same "side," in addition to the probably more well-known sectarian violence between groups on opposite sides.

${ }^{53}$ Jannie Lilja and Lisa Hultman, "Intra-Ethnic Dominance and Control: Violence against CoEthnics in the Early Sri Lankan Civil War," Security Studies 20 (2) (2011), pp. 171-197.

${ }_{55}^{54}$ Byman, "The Logic of Ethnic Terrorism," 157.

${ }^{55}$ Sambanis, Nicholas. "Do Ethnic and Nonethnic Civil Wars Have the Same Causes? A Theoretical and Empirical Inquiry (Part 1), Journal of Conflict Resolution 45, 3 (2001): 259-282.

${ }^{56}$ Richard Ehrlich, "Analysts See Link Between Sri Lanka Civil War and Assassination," Toronto Star, 1991; Kydd and Walter, "Sabotaging the Peace."

${ }^{57}$ Camber T. Warren and Kevin K. Troy, "Explaining Violent Intra-Ethnic Conflict: Group Fragmentation in the Shadow of State Power," Journal of Conflict Resolution 53 (3) (2015), pp. 484-509.

${ }^{58}$ Bapat and Bond, "Alliances Amongst Militant Groups."

${ }^{59}$ Bacon, Strange Bedfellows or Brothers in Arms; Tricia Bacon, "Alliance Hubs: Focal Points in the International Terrorist Landscape," Perspectives on Terrorism 8 (4) (2014).

${ }^{60}$ Asal et al., "With Friends Like These."

${ }^{61}$ Horowitz and Potter, "Allying to Kill." 
${ }^{62}$ See for example information from the Mapping Militants Program. http://web.stanford.edu/group/mappingmilitants/cgi-bin/groups/view/251 and http://web.stanford.edu/group/mappingmilitants/cgi-bin/groups/view/309. Accessed October 8, 2017.

${ }^{63}$ E.g., Bacon, "Strange Bedfellows," 61.

${ }^{64}$ Matthew Levitt, Hezbollah: The Global Footprint of Lebanon's Party of God (Georgetown University Press, 2005).

${ }^{65}$ Byman, Deadly Connections; Byman, The changing nature of state sponsorship of terrorism.

${ }^{66}$ Kanisha D. Bond, Power, Identity, Credibility, \& Cooperation: Examining the Development of Cooperative Arrangements Among Violent Non-State Actors. Dissertation, The Pennsylvania State University, 2010.

${ }^{67}$ Asal and Rethemeyer, "The Nature of the Beast;" Jones and Libicki, How Terrorist Groups End.

${ }^{68}$ Karmon, Coalitions Between Terrorist Organizations.

${ }^{69}$ Glenn H. Snyder, Alliance Politics (Ithaca: Cornell University Press, 1997).

${ }^{70}$ Adam Chandler, "The Islamic State of Boko Haram?” The Atlantic, March 9, 2015.

${ }^{71}$ Jackson, Brian A., with John C. Baker, Kim Cragin, John Parachini, Horacio R. Trujilo, and Peter Chalk, Aptitude for Destruction Volume 1: Organizational Learning in Terrorist Groups and its Implications for Combating Terrorism (Santa Monica: RAND, 2005), p. 11.

${ }^{72}$ Bond, Power, Identity, Credibility, \& Cooperation, pp.65-68.

${ }^{73}$ Mark Juergensmeyer, "Sacrifice and Cosmic War," Terrorism and Political Violence 3 (3) (1991), pp. 101-117; Magnus Ranstorp, "Terrorism in the Name of Religion," Journal of International Affairs 1 (50) (1996), pp. 41-62; Ayla Schbley, "Defining Religious Terrorism: A Causal and Anthological Profile," Studies in Conflict \& Terrorism 26 (2) (2003): 105-134; Mark Sedgwick, "Al-Qaeda and the Nature of Religious Terrorism," Studies in Conflict \& Terrorism 16 (4) (2004) 795-814.

${ }^{74}$ David C. Rapoport, "Fear and Trembling: Terrorism in Three Religious Traditions," American Political Science Review 3 (78) (1984), pp. 658-677.

75 Jessica Stern, Terror in the Name of God: Why Religious Militants Kill (New York: Ecco, 2003), pp. xxvi-xxvii.

${ }^{76}$ Bruce Hoffman, "'Holy terror': the implications of terrorism motivated by a religious imperative," Studies in Conflict \& Terrorism 4 (18) (1995), pp. 271-284, at pp. 272.

${ }^{77}$ E. g., Lindsay L. Heger and Danielle F. Jung, "Negotiating with Rebels: The Effect of Rebel Service Provision on Conflict Negotiations," Journal of Conflict Resolution 62 (6) (2017), pp. 1203-1229;

${ }^{78}$ Bruce Hoffman, Inside Terrorism (New York: Columbia University Press, 2006), pp. 88-89; Enders and Sandler, The Political Economy of Terrorism, pp. 55-56.

${ }^{79}$ Mark Juergensmeyer, "The Logic of Religious Violence," in David C. Rapoport ed., Inside Terrorist Organizations (London: Frank Cass, 2001), pp. 172-193, at. pp. 89-90.

${ }^{80}$ See, for example, Moghadam, Assaf, "Motives for Martyrdom: Al-Qaida, Salafi Jihad, and the Spread of Suicide Attacks," International Security 33, 3 (2008/2009): 46-78). While jihadists are the primary religious terrorist groups today, other terrorist groups with religious elements have included Japan's Aum Shinrikyo, Uganda's Lord's Resistance Army, and some white supremacist groups. Research has found that religious groups in general (not just jihadist groups) 
are more violent than other types of terrorist groups (e.g., Asal and Rethemeyer, "The Nature of the Beast.").

${ }^{81}$ Asal and Rethemeyer, "The Nature of the Beast"; Horowitz and Potter, "Allying to Kill."

${ }^{82}$ For example, Horowitz, "Nonstate Actors and the Diffusion of Innovation."

${ }^{83}$ Phillips, "Terrorist Group Cooperation and Longevity"; Brian J. Phillips, "Enemies with Benefits?"

${ }^{84}$ Asal and Rethemeyer, "The Nature of the Beast."

${ }^{85}$ While group size, for example, is likely to change regularly, gathering such time-varying information on clandestine groups around the world and over many years presents substantial hurdles. The size variable is discussed more below. If the time-series data set is used, most results are similar. However, observations are unlikely to be independent since there are many observations (years) for long-surviving groups that do not change much. To collapse the data into cross-sectional format, for the dependent variables, the maximum value at any point between 1987 and 2005 is used. For most independent variables, if they change over time, the first value of the variable in the temporal sample is used. This helps reduce the likelihood that relationship status in one year is affecting the subsequent values of independent variables.

${ }^{86}$ Ian Anderson, Victor Asal, and Karl Rethemeyer, Big Allied and Dangerous Codebook (New York: University at Albany - State University of New York, 2009).

${ }^{87}$ The GTD has relatively liberal criteria for terrorist attacks, so some groups were excluded if they, for example, only attacked military targets in a war environment, or are better described as criminal organizations. This is consistent with the group coding of Cronin, How Terrorism Ends, and others.

88 This variable differs from Asal and Rethemeyer's "negative relationship" variable in that their variable can include intergroup competition or disagreement that does not manifest itself physically. The data use my coding of violent rivalry.

89 This marks the difference between the coding currently used and Asal and Rethemeyer's "positive relationships" variable. They code groups as being in such a relationship if they had one of a broad variety of positive interactions, including if one had expressed solidarity for each other. I used a more specific conceptualization of alliances, more consistent with Karmon's notion of a "coalition," so I re-coded the Asal and Rethemeyer variable. (Karmon indicates that ideological cooperation on its own "does not qualify as a coalition relationship," p. 50.) The present study uses this more specific understanding of alliances because it is more likely to be a meaningful type of relationship.

${ }^{90}$ These categories are overlapping, non-exclusive, because a small number of groups are in both inter-field and intra-field rivalries. If these groups are excluded from the analysis, or exclusive codings are used, results are similar. The disaggregated alliance measures are also non-exclusive. ${ }^{91}$ Asal and Rethemeyer, "The Nature of the Beast;" Phillips, "Terrorist Group Cooperation and Longevity;" Phillips, "Enemies with Benefits?"

${ }^{92}$ Karmon, Coalitions Between Terrorist Organizations.

${ }^{93}$ Jan Teorell, Marcus Samanni, Soren Holmberg, and Bo Rothstein, The Quality of Government Dataset, edited by University of Gothenburg: The Quality of Government Institute (Gothenburg: The Quality of Government Institute, 2011).

${ }^{94}$ James D. Fearon and David D. Laitin, "Ethnicity, Insurgency, and Civil War," American Political Science Review 1 (97) (2003), pp. 75-90, at p. 80. 
${ }^{95}$ S. Brock Blomberg, Rozlyn C. Engel, and Reid Sawyer, "On the Duration and Sustainability of Transnational Terrorist Organizations," Journal of Conflict Resolution 2 (54) (2010), pp. 303330.

${ }^{96}$ Groups in country and population are correlated at .12.

${ }^{97}$ Teorell et al., The Quality of Government Dataset.

${ }^{98}$ Quan Li, "Does Democracy Promote or Reduce Transnational Terrorist Incidents?," Journal of Conflict Resolution 2 (49) (2005), pp. 278-297; S. Brock Blomberg, Khusrav Gaibulloev, and Todd Sandler, "Terrorist Group Survival: Ideology, Tactics, and Base of Operations," Public Choice 3-4 (149) (2011), pp. 441-463.

${ }^{99}$ David L. Cingranelli, David L. Richards and K. Chad Clay, The CIRI Human Rights Dataset, (2014). Available at www. humanrightsdata.com.

${ }^{100}$ The correlation is around .5. If one of the variables is excluded from models, other results remain similar, suggesting multicollinearity is not a threat to inferences.

${ }^{101}$ Gleditsch, Nils Petter, Peter Wallensteen, Mikael Eriksson, Margareta Sollenberg and Håvard Strand. "Armed Conflict 1946-2001: A New Dataset," Journal of Peace Research 39(5) (2002): 615-637.

${ }^{102}$ Christopher Zorn, "Comparing GEE and Robust Standard Errors for Conditionally Dependent Data," Political Research Quarterly 3 (59) (2006): pp. 329-341.

${ }^{103}$ Woldemariam, "Battlefield Outcomes and Rebel Cohesion."

${ }^{104}$ Thomas, Jakana, "Rewarding Bad Behavior: How States Respond to Terrorism," American Journal of Political Science 58 (4) (2014): pp. 804-818.

${ }^{105}$ Stedman, Stephen John, "Spoiler Problems in Peace Processes," International Security 22 (2) (1997): 5-53. 